\title{
No end to Nepal's Maoist rebellion
}

\author{
Joanna Pfaff-Czarnecka
}

\begin{abstract}
Since 1996, Nepal has increasingly been drawn into a violent conflict between Maoist rebels and the state, leading to a severe crisis. Thousands of civilians have been killed, and most people in the countryside live in constant fear. Economic hardship has seriously increased. Despite repeated efforts to bring the parties together for peace talks, there is little hope that the violent situation will be resolved in the near future. This article analyzes the complex causes of the emergence of the Maoist insurrection and its success, and sketches the problems impeding a democratic solution to the current situation.
\end{abstract}

Keywords: democratization, governance, Nepal, social disparities, violent conflict

During the last century and a half, Nepal has experienced comparatively few situations of overt conflict. Since 1996 however, this trend has been significantly reversed as a civil war emerged between an expanding Maoist movement and the state, taking about 12,000 lives until today (July 2005). Most of the population is caught in the crossfire between the two opposing sides-the state's armed forces and the Maoists. International organizations, notably Amnesty International, have repeatedly reported serious human rights abuses. Tremendous insecurity and fear have become an everyday-life experience for many Nepalese. ${ }^{1}$

During this comparatively short period of time, the country has changed visibly. The urban centers have grown in size, taking in people who abandoned their homesteads in rural areas in search of protection in the city. Especially the country's capital, Kathmandu, is booming for this reason. Simultaneously, tourism has drastically decreased. Traveling in Nepal has become a perilous endeavor as motorways are often blocked and there is the danger of bombs placed by Maoist soldiers. All over the country check posts have been established, not only by the state, but also by the Maoists. While visitors from Western countries are usually allowed to pass, many Nepalese have been harassed and detained.

The public sphere has been considerably restricted. Increasingly, the governmental control of mass media has impeded the availability of information and the exchange of opinion. Most international development agencies have reduced their projects outside the Kathmandu Valley. The scope of academic research has been reduced as well. Especially American colleagues are reluctant to face confrontations with Maoist warriors, fearing their resentment. Since the turn of the millennium (according to the Western calendar), the situation has changed from bad to worse. Short periods of ceasefire and attempts at 
peace talks have been interspersed by prolonged periods of escalating violence and the tightening of the Maoists' grip over the countryside. Political forces have been caught in an impasse for several years now and there is little reason to assume that the situation will be resolved in the near future.

\section{Historical context}

Nepal, situated at the southern slopes of the Himalayan range between the borders of China and India, has historically been a country of intense religious and ethnic hierarchies. More than sixty ethnic groups live on Nepalese territory, along with the dominant Hindu Parbatiya population. The country came about in its present size when in the mid-eighteenth century the House of Gorkha started its military expansion. Until 1814, about sixty principalities and ethnic regions came under the sway of the Shah dynasty, whose conquests however came to a halt when they were confronted with the British colonial forces. Nepal never came under British colonial rule; it remained closed to the outside world, by and large, especially after the Rana family seized power in 1846. Throughout the nineteenth and the first half of the twentieth century the rulers managed to centralize their kingdom, establishing direct rule in most areas of the country and bringing a large share of the fertile land under their control. By facilitating the migration of the Parbatiya population to the ethnic territories, they actively contributed to ethnic lands shifting hands to the rulers and their political allies and clients. In 1854 the Ranas promulgated the first civil code (Muluki Ain), formalizing the hierarchically ordered caste society with clear-cut ranks. To a large extent, membership in a rank decided about one's rights and duties.

Nepal opened to the world in the year 1951 when the Rana regime was overthrown. Growing popular protest had won momentum when the powerless King Tribhuvan of the Shah dynasty, stripped of most power prerogatives by the Ranas but still kept in office, managed to escape to India and to come back shortly afterwards with Indian support. Celebrated as a 'hero of revolution', King Tribhuvan became the leading figure in a political transition toward democratization-which however paradoxically coincided with a strengthening of the monarchy. During the 1950s, most exiled oppositional forces returned to Nepal. While in India, the oppositional politicians had formed political parties, notably the Nepali Congress and the Communist Party of Nepal. After the death of King Tribhuvan in 1955, his son King Mahendra initially tolerated efforts toward establishing a pluralist democratic system. However, after the first popular elections were held in the year 1959, he dissolved the parliament only eighteen months later, introducing a party-less Panchayat system that was to last until 1990.

It was King Mahendra (on the throne from 1955 to 1972) who initiated the modernization of Nepal, attracting development agencies, skillfully harnessing political rivalries during the Cold War, and exploiting Nepal's delicate geopolitical position. He embarked upon the strategy of state-driven development, following five-year plans, and promoted assimilationist policies. His cultural style was depicted as 'Nepalization': imposing cultural-religious elements of the high-caste elite, while declaring ethnic cultures as backward and their promotion as dissident. Although his government cannot be called entirely autocratic, King Mahendra, and his successor son King Birendra (1972-2001), did manage to combine all powers upon themselves and seriously curtailed human rights-most notably the right to information and to organization. Political opposition had to go underground, or into exile, once again. However, popular protest never ceased to exist. In the late 1970s and throughout the 1980s civic protest gained momentum in Nepal, escalating in the spring of 1990.

After forty persons were killed by the armed forces in April 1990 in Kathmandu, King Birendra faced serious criticism, both internally and from the international community. Consequently, he agreed to give up some of his powers, to reintroduce a multi-party political system, and to promulgate a new constitution that for the first time in Nepal's history declared the 
population, rather than the king, sovereign. He formed an interim government to be headed by members of the Congress Party and in May 1991 general elections were held. The political process was strongly dominated by elder political figures within the Congress Party and numerous Communist leaders who had spent large portions of their lives in exile, often in prison, and whose charisma derived from prolonged oppositional battles.

In the first popular elections since 1959, the Rashtriya Prajatantra Party that was closely associated with the royal house and the former Panchayat system therefore lost severely, gaining only 12.5 percent of the total seats. Instead, the elections were won by the Party of Congress with 39.5 percent, followed closely by Communist parties that together won 38.1 percent (the Communist Party of Nepal 29.3 percent; the United People's Front 5 percent; the Communist Party of Nepal (Democratic) 2.5 percent; and the Nepal Worker's and Peasant's Party 1.3 percent). By and large, this election "demonstrated the dramatic growth of Nepali communism as an electoral force, at a time when communist parties worldwide appeared to be in rapid decline in the wake of the collapse of communism in Eastern Europe" (Nickson 2003: 24). One of the Communist parties, the Masal Party, which later transformed into the Communist Party of Nepal (Maoist), however, boycotted the elections. It was this party that carried forward the Maoist movement.

As in many other parts of the world, the early 1990s seemed a hopeful beginning of democratization that was expected to expand in scope and depth. The 'spring awakening', as this short period was called in Nepal, raised high hopes and expectations throughout the country. This joyous and dynamic mood was not to last. Already shortly after the first general elections, rifts within the major Nepalese political parties became noticeable, matched by the persistence of hierarchical tendencies such as subordination, nepotism, as well as a strong cult of elevated personalities within the party ranks. In the Nepali Congress, a split between its three charismatic leaders Krishna Prasad Bhataraj, Ganesh Man
Singh Shrestha, and Girija Prashad Korala could not be prevented. Turbulent disagreements and realignments were a central feature in the Communist parties' dynamics as well.

In 1994, following the prime minister's recommendation, the king had to dissolve parliament. After new elections, a Communist government was formed. This government was however also not to last. In effect, between 1991 and 2002, eleven subsequent governments were formed and dissolved. On 1 June 2001, the king and most of his closest relatives were killed by King Birendra's son Crown Prince Dipendra, who most probably was under the influence of drugs and alcohol. The assassination of the royal family brought about a considerable shift in the government's stance vis-à-vis the Maoists. After the royal massacre, King Birendra's younger brother, Gyanendra was enthroned. While King Birendra had been reluctant to deploy the army against the Maoist movement, King Gyanendra perceived the involvement of the armed forces as a serious option in bringing the Maoist movement to a halt. With this aim, the Nepalese army was substantially enlarged and trained. Simultaneously however the Maoist movement gained strength. Though the Maoists reduced their public presence during the weeks after 11 September 2001, when they had to fear external interference, their violent actions reappeared in a reinforced manner from late 2001 onward. In the course of the new millennium, the number of attacks and the loss of lives has increased considerably.

\section{The Maoist movement's expansion}

The complex trajectory of the formation of the Masal Party can only be roughly sketched here. In the years 1989 and 1990, an alliance of parties had been formed striving to overthrow the Panchayat regime. Baburam Bhattarai, one of the masterminds of the Maoist movement, was then the leader of the Mashal Party (note that 'Masal' and 'Mashal' are not identical). Immediately after the Panchayat overthrow, he voiced severe criticism vis-à-vis fellow parties united in the movement for prematurely terminating 
the People's Movement rather than wresting greater concessions from the monarchy. He lead several instances of protest, for instance fiercely criticizing the king's attempt to form a Constitution Recommendation Commission without consulting the interim government, and loudly opposing the India-Nepal treaty on trade. Along with other communist parties, the Mashal was particularly against the inscription of Nepal as a constitutional monarchy in the new constitution. Baburam Bhattarai moreover denounced the upcoming elections as illegitimate and on this ground dissociated himself from 'mainstream' Communist parties. Eventually Mashal broke up. The more moderate wing joined the electoral process under the banner of the United People's Front, whereas Baburam Bhattarai's Masal fraction boycotted the elections and traveled particularly to western Nepalese districts in order to build up their support base. Between 1991 and 1996, they prepared the ground for the armed movement to gain momentum.

From the very beginning, the Maoist leaders' declared objective was to gradually grow and expand their armed force to such an extent that battling the country's security forces and taking over power would become possible. In order to achieve this goal, they designed a sixpoint plan, according to which action was carried out (Sharma 2004: 373f.). The period of the first plan, which started in 1996 and lasted for a month, was called "Let's move ahead on the path of the People's War to establish the new people's democratic state by destroying the reactionary state." It put the movement's activities in motion and made it acquire public attention through various publications and acts of destruction. The period of the second plan lasted from March 1996 to June 1997, following the slogan "Develop the People's War in an organized way." By attacking police stations, the Maoists were able to capture weapons. Directed killings of selected enemies, the first being two policemen in the district of Rukum in May 1996, also started.

Then came the third plan, lasting from June 1997 until October 1998. Under the motto "Raising the development of guerrilla warfare to new heights," the Maoists continued to expand their armed force, actively preventing local elections and forcing elected representatives to resign. Wherever a power vacuum was created, the Maoists started establishing their own governments. In February 1998, the Maoists launched their central military commission. From October 1998 until August 1999, during the fourth plan, the movement followed the slogan "Let's embark on the great path of creating base areas," conducting simultaneous attacks in many districts of the country. A rally in New Delhi in February 1998 revealed the support of six Indian organizations. In Nepal, the Maoists raided police posts more frequently than before in order to seize arms and ammunition. They also repeatedly attacked telephone towers and banks and blasted government offices in the district headquarters. Under the fifth plan, enacted from August 1999 until July 2000, the movement continued building up its bases in a growing number of districts. In September 1999, the Maoist army was capable of carrying out simultaneous attacks in twenty-five districts (out of seventy-five Nepalese districts in total). In October 1999, the movement organized its first Nepal Bandh (total strike), enforcing the closure of offices and shops and restricting movement. Finally, the sixth plan, lasting from July 2000 until February 2001, went under the slogan of "Raise to new heights the guerrilla war and the people's resistance struggle." During this period, positions were reinforced, imposing a tight grip over large parts of the countryside. On the occasion of their second national conference, the Maoists revised their objectives, abandoning the narrow path of the 'People's War' and adopting instead the 'Prachanda Path' with the program "Let us consolidate and expand our base areas and move forward towards a people's government in the center" (Sharma 2004: 375).

With their success in establishing people's governments in several Nepalese districts and in enclosing the Kathmandu Valley, the Maoists rendered the movement more successful than they had probably dared to hope for (Thapa and Sijapati 2003). Though they did not manage to occupy any of the district capitals, the tight grip over the Kathmandu Valley that the Maoists 
achieved through blocking access roads, and thus impeding transport to the capital, had a far-reaching material and symbolical effect on the country. From the very beginning the Maoists managed to mark out their political space in the country through violence. They demonstrated remarkable logistic skills and military strength by staging attacks on police headquarters, the first in October 2000 at a district police office and a district jail in Dunai (Dolpa district), the second in Ghorahi (Dang district), the third in Syangja, and the fourth, in November 2001, in Salleri (Solukhumbu district). On the occasion of these attacks, policemen (and soldiers in Ghorahi) were killed and abducted and abundant arms, ammunition, vehicles, and cash captured. The Maoists also repeatedly attacked rich rural households and abducted thousands of mostly young men and women. Many of them were incorporated into the ranks of the Maoist army after having undergone ideological and martial training. Others were abducted for a short period of time, in which they mainly received Maoist teachings. Yet another pattern obtains where villagers were incorporated into the Maoist ranks as helpers (for the transportation of ammunition and of wounded Maoist soldiers, the preparation of food, etc.). The movement thus managed to considerably expand its resource base through its attacks, capturing money and weapons, which were in turn used to stage subsequent attacks.

Maoist violence met with state violence particularly from 1998 onward when the government launched its counter-insurgency police operation called 'Kilo Sierra 2'. After the Salleri attack, in November 2001, the government declared a 'state of emergency' across the country and deployed its police force in full scale against the Maoists. Under the state of emergency, which lasted for nine months, the Maoists carried out their largest action till then in western Nepal. In February 2002, some two to three thousand Maoists surrounded Mangalsen, the district headquarters of Acham, and attacked the army garrison and the district police office. After the attack at Dunai, the army was deployed to sixteen district centers. Police were significantly reduced and concentrated in district headquarters, with the Royal Nepalese Army becoming more and more in charge of security and certain development programs, especially those in the field of infrastructure. While the state increasingly deployed the Royal Nepal Army to control the insurgency, the Maoists continued to develop their military organization. The strength of the Maoist army is currently estimated at between 10,000 and 15,000 well-trained fighters, known as the movement's 'hard core', and an additional 50,000 militia. Around 40 percent of Nepal's territory is believed to be under Maoist control at present.

After its impressive expansion, the movement put forward a strong political party named the Communist Party of Nepal-Maoist (CPN-M), formed according to Mao Zedong's principle, which states that

"the party, the people's army and the unified front are the three weapons for a people's revolution ... While the party itself is involved in spreading the party's ideology as well as formulating policies related to the 'people's war', the people's army is responsible for attacking 'enemies' and defending the areas under its control" (Sharma 2003: 362).

The CPN was formed with the 'standing committee' at the top, and below it the politburo, central committee, regional bureaus, sub-regional bureaus, district committees, area committees, and cell committees. When the central committees cannot hold a meeting, the party's chairman Prachanda, takes all decisions (Sharma 2003: 362).

Many explanations have been given for the Maoist movement's success in Nepal. One reason lies in the organizational capabilities of its leaders. Both key figures, Baburam Bhattarai and Comrade Prachanda, have developed impressive skills in promoting Maoist ideology and mobilizing protest in the Nepalese context. Their success lies partly in their ability to establish a broad and direct base among the population, starting from the western Nepalese regions (especially in the districts of Rolpa and Rukum). Unlike most political and administrative personnel, who are 
used to keep a social distance from their constituencies, both these leaders have been able and willing to interact directly with the local population. Such intimate contacts have helped them gain legitimacy by enabling them to grasp local grievances as well as popular ideas on legitimacy. They have also been very successful in adopting Chinese and Soviet models of armed struggle and of organizing armed insurrection. By 1996, the leaders had established a hierarchically ranked and efficient 'Maoist army' whose central features included obedience and dedication. The thread and use of force was deployed, moreover, side-by-side with local reforms that met certain local grievances. Thus, the leaders managed to convey their seriousness vis-à-vis the people of Nepal, the government, as well as the international community (Thapa 2004).

The ideologies that the Maoists embrace are by no means new to the population in Nepal or South Asia in general. Leaders resort to regional (i.e., South Asian) repertoires of leftist ideologies and models of action that have been deployed all over the Indian sub-continent for decades. Indeed, South Asia-including Nepal, particularly its southern and eastern regionshas seen various instances of left-wing mobilization, desperate forms of civil disobedience, and prolonged periods of armed conflict. The influence of the Naxalite movement (active especially in north-east India) is particularly prominent, but by no means unique (Ramirez 2004). Previous movements have left a rich legacy behind, providing guidance on how to organize and suggesting discourses on injustice and modes of self-representation. The People's revolution in China continues to provide an important role model. (However, the Chinese government has made it explicit on several occasions that it did not support the movement in Nepal.)

Additionally, the manifold global patterns of left-wing insurrection have provided the leaders with a roadmap of how to organize their army, which ideological means to embrace, and which symbolic elements to deploy. Inspiration from Peru's Sendero Luminoso is obvious in this respect (see Mikesell 2003). ${ }^{2}$ When the Masal Party went to the streets in protest shortly after the elections of 12 May 1991, it called for a People's War in Nepal

"along the path shown by the Communist Party of Peru, which has been fighting against US imperialism, Soviet social imperialism, and local reactionary forces and is attaining victory in the new people's revolution. All this indicates a bright future for the international communist movement" (according to Masal's politburo, quoted in Nickson 2003: 31).

Nepal's Maoist movement has also been decisively privileged by the country's rugged terrain (comparisons with Afghanistan and Peru come to mind). The Maoist armed forces have been able to withdraw into the woods on many occasions, after their attacks. Given Nepal's rugged topography and the great lack of roads, it seems impossible to stop the Maoist movement by means of armed struggle. The successful use of force by the Maoists has certainly contributed to their influence over the population, but, during the first years of its operation at least, the movement's catering to local grievances and aspirations also played a decisive factor.

\section{The Maoist movement-addressing people's grievances}

With the all too frequent elections and votes of mistrust, political instability in Nepal was obvious. By the mid-1990s, most of the population also came to realize that political transition had failed to bring about noticeable social or economic changes. High hopes and expectations regarding democratization could not be sustained (Pfaff-Czarnecka 2004). From the very beginning when the Maoist movement started its activities in 1996 in western Nepal, its leaders Baburam Bhattarai and Comrade Prachanda decried the fact that the poor majority of the population, notably the 'untouchable' (today: 'dalit') and ethnic groups, had not gained in any respect under the new system. They accused the political elites in Kathmandu of protecting and expanding their own interests without introducing any significant 
reforms to elevate the wanting socio-economic conditions prevailing in the country at large.

Nepal's poverty, its pronounced hierarchical social order, and its multiple forms of marginalization and exclusion clearly form the background if not to the movement's coming to life, then certainly at least to its initial attractiveness for many people. The diverse attempts of the Maoists at social reform were important incentives for the local population to turn to the movement. In the same vein, the Maoist movement is a young people's movement (Onta 2004). Especially crucial in this respect is the perception of many young people that they lack opportunities given the wanting economic situation in their country. With the very slow pace of development many young people had little hope of being incorporated into the labor market. Literacy rates had increased over the preceding decades. During the 1990s, however, the number of school drop-outs increased. For a growing number of young men and women engagement in the Maoist movement seemed an alternative, given the scarcity of governmental and industrial jobs.

The Maoist leaders are seen to have addressed many burning popular issues. The leaders have repeatedly stated their commitment to reducing rural disparities and have denounced bonded labor, untouchability, and irregular housing. On several occasions, the Maoists have attacked caste inequalities as well as women's oppression. Equal access to education and to health are particularly prominent objectives. Ethnic oppression and ethnicity-based disparities likewise have a prominent place in Maoist mobilization (Sales 2003). The leaders have endorsed many of the objectives formulated by ethnic organizations, being particularly supportive of the plan to establish eight ethnic autonomous regions on Nepalese territory. Furthermore, the Maoists have adopted nationalist discourses, seeking to reduce the Indian influence on Nepal's economy, politics, and society.

Another reason for the Maoist movement's success, at least in its initial stage, lies in the massive disappointment among people all over Nepal with the performance of politicians and administrators. After 1990, expectations had risen significantly and people assumed that development efforts would speed up. At the initial stage of the democratization process, many changes were introduced. The most remarkable among them were the constitutional reforms, including the division of powers, the protection of diverse political and civic freedoms, the multiculturalist orientation of society newly inscribed into the 1990 constitution, and the reintroduction of a multi-party system. Additionally several administrative reforms took place, notably renewed attempts at decentralization and the streamlining of the state apparatus. As in many other countries, the Nepalese democratization process however coincided with global pressures for 'structural adjustment.' The idea that public social services would improve through anti-corruption laws and the reduction of bureaucracy, which would make them more efficient and less nepotistic, seemed attractive to the general public. Mixed feelings emerged, however, as the reality of a reduction in cherished employment opportunities in the civil service, to which many young people had aspired, became obvious. High expectations for political democracy were thus confronted with exclusionary and centralizing economic policies, with particularly serious consequences for the rural population.

The pretence of greater efficiency in service delivery moreover proved hollow as local leaders continued to misappropriate the available development funds and still lacked the ability to carry out development activities in an efficient manner. Despite liberal reforms, the old hierarchies and elite networks centered on the capital reproduced themselves in the new political networks and social and regional spoils after the 1990 'revolution'. The state remained the overriding mechanism of accumulation and vehicle for private enrichment. The intermediary structures involved can be grasped through the concept of 'distributional coalitions' (PfaffCzarnecka 2004). Distributional coalitions can be seen as a modality of capture which politicians, bureaucrats, and entrepreneurs exert in order to channel money and services allotted to local communes into their own pockets. The 
analysis of these intermediary structures reveals the problematic of state-society relations in democratization processes: partners forming distributional coalitions can exploit the wanting accountability system, while drawing upon old established social models of patronage and clique-building (Shaha 2003). By doing so, they feed popular mistrust and take advantage of the local sense of helplessness vis-à-vis the state.

Disappointment both in the field of economic well-being and political reform made local people open to political alternatives. Indeed, as persistent economic stagnation combined with deficiencies in political development, it became impossible for the vast majority of Nepal's people to participate in public political processes and institutions. Many of them looked for an alternative vision of political transition, which Maoist leaders provided. They criticized the detrimental effects of externally induced reforms upon the well-being of a marginalized population and accused local politicians and contractors (often the same persons or persons belonging to the same family) of corruption, nepotism, and deal making with state administrators in charge of allocating development and other public funds. The disenchantment of many people all over the country with the path Nepalese politics had been taking is thus crucial in explaining the appeal of the Maoist movement. This trend may not be apparent among the inhabitants of the Kathmandu valley, but it certainly shows up in less accessible areas of the country where the success of the Maoist movement is inevitably linked to the failure of the project of democratization.

\section{The effects of the Maoist insurrection}

Little is known about the effects of the new modes of Maoist governance. By 2003, Maoists had established Jan sarkars (Maoist governments) in twenty-one districts (see, e.g., Shneiderman and Turin 2004). A few years ago, the government created a list of sensitive areas (dividing them according to the assessed risks into $\mathrm{A}, \mathrm{B}$, and C) comprising thirty-five districts-out of seventy-five districts in total. These areas are under
Maoist control, up to different degrees, while in six districts (Rolpa, Rukum, Jajarkot, Salyan, Pyuthan, and Kalikot) government presence remains restricted to the district headquarters as Maoists have taken over the rest.

In the areas under their rule, Maoists managed to force out elected village committees and established their own structures. An important layer in this design are people's committees at the ward, village, area, and district levels. These are divided into particular categories such as janjatis (ethnic groups), dalits, women, intellectuals, guerrillas, businessmen, and others. They are elected from their own ranks. Land-owning families and those involved in surplus appropriation are not allowed to participate in the people's government. The local committees are organized according to three dimensions: political, economic, and socio-cultural. Politically, the people's committees came to completely replace the elected village development committees (VDCs). People's courts were created where judgments and sentences are passed-in a highly arbitrary manner, according to many reports.

An important aim stated by the Maoists is to render the communes' economy self-sufficient. Among the major Maoist economic reforms are diverse new forms of taxation and money lending. Persons earning salaries, such as local teachers and bureaucrats, have to contribute a share of their salaries, up to a month's salary per year. But also people in menial positions-such as firewood collectors-need to make contributions to the Maoist treasure. (As a consequence, hardly any taxes flow from these areas into the state's treasure.) In those districts where land was captured from 'feudal landlords', communal enterprises have been started. In some villages the Maoists even began land registration.

All over the country, the Maoists have actively engaged themselves in instigating social and cultural reforms, or have claimed to do so. The provision of health services ranks high on the Maoists agendas-which means above all that development projects aiming at health care have not been targeted so far. This measure is also conditioned by the Maoist interest in being able to take care of wounded soldiers. Especially prominent in the 
Maoists' programs is schooling. There is some evidence that in certain Maoist areas the level of education, and especially the awareness among women, has gone up (Sharma 2004: 369). Teachers however work under extremely difficult conditions, often targeted by both police and Maoists. Within the school curriculum Communist doctrines have been introduced, while Sanskrit lessons have been banned. Several social reforms have been introduced in the Maoist areas. Apparently, alcoholism, gambling, and crime have been significantly reduced in villages under the Jan sarkars (Sharma 2004: 369).

Local customs have been actively discouraged. The Maoists have especially opposed celebrating the important Hindu festivals Dasain and Tihar. In their place new celebrations have come about, such as those to commemorate people fallen in the People's War-especially on the occasion of Martyr's Day. The Maoists have repeatedly been reported as forcing Brahmins to cook pork in their kitchens-a severe transgression to the rule of ritual purity. The Maoists actively discourage villagers from bearing high costs to conduct rituals or generally investing overtly in religious activities.

From the very beginning of the Maoist insurrection, the local population has come to suffer severely. Repeatedly, villagers-especially young men but also their families-have been accused by police forces of either being Maoists themselves, or helping the Maoist movement. On the other hand, entire families and villages were put under pressure by the movement to provide them with food and shelter. Also, many people have been abducted. They either had to undergo Maoist training before being set free, or had to remain in the movement. If it started initially as an all-male movement, increasingly young women have been drawn into it (Gautam, Banskota, and Manchanda 2003). Concomitantly, violence against women went up significantly. Vulnerable groups, such as porters, are often harassed at Maoist check-posts where they have to leave part of their load behind (Centre for Investigative Journalism 2004: 77ff.).

Many land-owning families had to abandon their homes and settle in town. Many homesteads have been abandoned, and fields lie fallow. On uncountable occasions, civilians have been caught in the crossfire between governmental armed forces and Maoists. Besides loss of life, there has been a serious destruction of infrastructure. In several districts, administrative buildings and bridges have been destroyed by the Maoists. A few instances of protest against these destructions have been reported. A local women's protest in the district of Dailekh made big headlines by mid-2004: the women fiercely opposed the Maoists and managed to drive them out of the village, but continue to fear retaliation.

Nepal's economy is going from bad to worse and foreign inflows of money, including from tourism and international development agencies, have fallen. Strangely, life in the capital seems to be largely unaffected by the economic deterioration: Kathmandu is booming due to the very high influx of population fleeing the Maoists. Civil society activists, politicians, and civil servants have repeatedly expressed their concern over the situation in the countryside. Nevertheless, one cannot ignore the strong impression that life in Kathmandu is going on as usual despite the tremendous suffering throughout the countryside. This impression is matched by a villager's opinion:

"There may be an indefinite banda (strike) in Doti, all schools may be closed in Kailali, health posts in Bajura may be without medicine, there may be a food shortage in Humla. But who cares? The people of Western Nepal stopped expecting anything from Kathmandu long ago" (Nepali Times Online, 13 July 2005).

\section{Outlook}

On 1 February 2005, King Gyanendra dissolved the parliament and sent Prime Minister Sher Bahadur Deuba out of office. He sacked the government and assumed direct powers. He moreover imposed a three-month state of emergency, legitimizing this step by claiming that the government had not been able to resolve the Maoist conflict. Notably, the king accused Prime Minister 
Deuba's government of failing to win the support of Maoist rebels for a January deadline for peace talks and of failing to prepare the ground for elections in spring. Most observers assume, however, that an important driving force has been the king's hidden agenda to strengthen his own role in Nepalese politics. An important consequence is the censorship imposed upon the media as well as the impediment of free movement in the country. Furthermore, many party leaders have been put under house arrest (some of them have even been thrown into jail), and are threatened by the Royal Commission of Corruption Control, which is widely believed to be an instrument of political control under the current situation.

Following his initial announcement, King Gyanendra lifted the state of emergency after three months, but still retained his powers. There is no sign of upcoming elections, which is not surprising, given the Maoist dominance in much of the countryside. The prospects for peace talks in the near future are not large. So far, the parties have not yet even been able to agree who is to participate in them. The state's main precondition in order to initiate talks on the Maoists' future role in the formal political system is a ceasefire. The Maoists on the other hand made their claims known already in 1996 by issuing a forty-point demand letter to the prime minister. ${ }^{3}$ It remains to been seen which demands will be an object of compromise. With an impasse between the Maoists, the king, and the political parties, there is also no agreement on accepting international intermediaries. Since February, the Maoists have not ceased to conduct violent action. For the first time they have even directly targeted civilians, blowing up a bus and killing over forty passengers.

Given the complexity of the causes that have enabled the emergence and the expansion of the Maoist movement (Hachhethu 2004; Shah 2004), no simple solution to the violent conflict is likely. Nepal's continuing existence as a constitutional monarchy however seems particularly problematic. Maoist leaders have repeatedly reiterated that they would not agree to a political system dominated by a monarch. King Gyanendra's coup of 1 February has moreover created a lot of criticism in Nepal, South Asia, as well as among the international community. A reintroduction of the division of powers will therefore most certainly be an important minimal condition put forward vis-à-vis the monarch (Roka 2004).

Most Nepalese seem to hope for a return to the spirit of the constitutional reforms initiated in 1991, for an end to the hostilities, and for a national dialogue toward a negotiated solution. It remains to be seen whether an acceptable mode of governance, binding together state and societal forces and ameliorating the striking social cleavages and processes of marginalization and social exclusion persisting in the country, can emerge in the near future.

Joanna Pfaff-Czarnecka has been chair of the Social Anthropology Department at the University of Bielefeld, Germany, since 2001. She obtained her Habilitation degree in social anthropology at the University of Zurich, where she studied social anthropology, law, media studies, and European anthropology. Her interests focus on political transformation in South Asia and minority studies. Her publications include Ethnic futures: state and identity in four Asian countries with Ashis Nandy, Darini Rajasingham, and Terence Gomez; Rituale heute: Theorien, Kontroversen, Entwürfe, with Corina Caduff; and Nationalism and ethnicity in a Hindu kingdom: the politics of culture in contemporary Nepal, with David Gellner.

E-mail: joanna.pfaff@uni-bielefeld.de.

\section{Notes}

1. For more information, see particularly Dixit and Ramachandaran (2003), Hutt (2004), Thapa and Sijapati (2003), and Thapa (2003).

2. On a discussion of the parallels between Sendero Luminoso and the Maoists in Nepal see Nickson (2003). 
3. The forty-point demand list, formulated by the Maoist leaders and presented to the prime minister in 1996, included demands concerning nationality (points 1-9, e.g., point 1 "all discriminatory treaties, including the 1950 Nepal-India Treaty, should be abrogated"), concerning people's democracy (points 10-26, e.g., point 10 "a new constitution should be drafted by representatives elected for the establishment of a people's democratic system") and concerning livelihood (points 27-40, e.g., point 27 "land should belong to 'tenants'. Land under the control of the feudal system should be confiscated and distributed to the landless and the homeless").

\section{References}

Centre for Investigative Journalism. 2004. People in the 'people's war'. Kathmandu: Himal Books.

Dixit, Kanak Mani, and Shastri Ramachandaran, eds. 2003. State of Nepal. Patan Dhoka, Lalitpur, Nepal: Himal Books.

Gautam, Shobha, Amrita Banskota, and Rita Manchanda. 2003. Where there are no men: women in the Maoist insurgency in Nepal. In Thapa, 2003, 93-124.

Hachhethu, Krishna. 2004. The Nepali State and the Maoist Insurgency, 1996-2001. In Hutt, 2004, 58-78.

Hutt, Michael, ed. 2004. Himalayan 'People's War': Nepal's Maoist rebellion. London: Hurst and Company.

Mikesell, Stephen L. 2003. The paradoxical support of Nepal's Left for Comrade Gonzalo. In Thapa, 2003, 35-42.
Nickson, R. Andrew. 2003. Democratisation and the growth of communism in Nepal: a Peruvian scenario in the making? In Thapa, 2003, 3-34.

Onta, Pratyoush. 2004. Democracy and duplicity: the Maoists and their interlocutors in Nepal. In Hutt, 2004, 136-51.

Pfaff-Czarnecka, Joanna. 2004. High expectations, deep disappointment: politics, state and society in Nepal after 1990. In Hutt, 2004, 166-91.

Ramirez, Philippe. 2004. Maoism in Nepal: towards a comparative perspective. In Hutt, 2004, 225-42.

Roka, Hari. 2004. The emergency and Nepal's political future. In Hutt, 2004, 243-60.

Sales, Anne de. 2003. The Kham Magar country, Nepal: between ethnic claims and Maoism. In Thapa, 2003, 59-88.

Shah, Saubhagya. 2004. A Himalayan Red Herring? Maoist revolution in the shadow of the legacy Raj. In Hutt, 2004, 192-224.

Shaha, Rishikesh. 2003. Idea and reality, Nepal and Rolpa. In Thapa, 2003, 49-52.

Sharma, Sudheer 2004. The Maoist movement: an evolutionary perspective. In Hutt, 2004, 38-57.

Shneiderman, Sara, and Mark Turin. 2004. The path to Jan Sarkar in Dolakha district: towards an ethnography of the Maoist movement. In Hutt, 2004, 79-111.

Thapa, Deepak, ed. 2003. Understanding the Maoist movement of Nepal. Jamal, Kathmandu: Modern Printing Press.

.2004. Radicalism and the emergence of the Maoists. In Hutt, 2004, 21-37.

Thapa, Deepak, and Bandita Sijapati. 2003. A kingdom under siege: Nepal's Maoist insurgency, 1996-2003. Kathmandu: Printhouse. 